\title{
Peran Efektivitas Komunikasi dan Kepuasan Kerja Terhadap Kinerja Dengan Motivasi Sebagai Variabel Mediasi Pada Karyawan PT. SUCOFINDO (Persero) Cabang Pontianak
}

\author{
Thirza Ardisha a \\ *abc Magister Manajemen, Fakultas Ekonomi dan Bisnis, Universitas Tanjungpura, \\ Pontianak \\ *Email : thirzaardishatz@gmail.com \\ (Diterima September 2019; Disetujui Mei 2020; Dipublikasikan Juli 2020)
}

\begin{abstract}
Abstrak
Penelitian ini bertujuan untuk mengetahui Peran Efektivitas Komunikasi dan Kepuasan Kerja terhadap Kinerja dengan Motivasi Sebagai Varibel Mediasi. Metode penelitian menggunakan metode deskriptif kuantitatif dengan jumlah sampel sebanyak 73 yang terdiri dari pegawai tetap dan pegawai tidak tetap. Data diperoleh dari kuesioner yang disebar kemudian diolah dan dianalisis dengan menggunakan analisis jalur melalui Software SPSS 23. Hasil penelitian menunjukkan bahwa: 1. Efektivitas Komunikasi berpengaruh siginifikan terhadap Kinerja Karyawan, 2. Efektivitas Komunikasi berpengaruh siginifikan terhadap Motivasi, 3. Kepuasan Kerja berpengaruh siginifikan terhadap Kinerja, 4. Kepuasan Kerja berpengaruh siginifikan terhadap Motivasi, 5. Motivasi berpengaruh siginifikan terhadap Kinerja, serta 6. Motivasi berhasil memediasi Efektivitas Komunikasi dan Kepuasan Kerja terhadap Kinerja. Data yang dikumpulkan untuk diteliti dan dianalisis berdasarkan pada persepsi masing- masing responden terhadap item-item pada instrumen penelitian sehingga dapat memungkinan terjadinya bias atau miss perception.
\end{abstract}

Kata Kunci: Efektivitas Komunikasi, Kepuasan Kerja, Kinerja, Motivas

\section{PENDAHULUAN}

Seiringa berkembangnya zaman, persaingan global kian ketat, perkembangan teknologi kian maju, dan kondisi dinamis lainnya, menuntut setiap organisasi untuk dapat cepat beradaptasi dan semakin kompetitif dalam dunia bisnis yang dihadapi. Perusahaan membutuhkan struktur yang dapat tumbuh dan beradaptasi dengan lingkungan yang begitu dinamis. Perkembangan ini tentunya membuat perusahaan untuk merancang serta menentukan konsep dan sistem yang tepat agar dapat mempertahankan kelangsungan hidup perusahaan dan lebih lanjut lagi mampu untuk dapat memenangkan persaingan di era globalisasi yang kompetitif ini.

Denyut usaha yang efektif salah satunya didasarkan pada kesehatan komunikasi di dalamnya. Dalam seluruh bentuk organisasi, komunikasi akan digunakan sebagai media penyebaran dan pertukaran informasi yang akan mengontrol organisasi selalu berjalan di atas jalur yang telah ditentukan. Tanpa komunikasi, interaksi antar manusia baik secara perorangan, kelompok, ataupun organisasi tidak mungkin dapat terjadi. Komunikasi sangat penting bagi seluruh fungsi perusahaan, karena sistem operasional dan manajemen digerakan oleh komunikasi. Perusahaan harus mampu menaungi kegiatan antar karyawan dalam pengerjaan tugasnya. Selain komunikasi 
Peran Efektivitas Komunikasi dan Kepuasan Kerja Terhadap Kinerja Dengan Motivasi Sebagai Variabel Mediasi Pada Karyawan PT. SUCOFINDO (Persero) Cabang Pontianak

Thirza Ardisha a

yang efektif guna mendukung kinerja karyawan yang baik, kepuasan kerja dari para karyawan juga merupakan hal yang penting dalam mendukung kinerjanya. Menurut Robbins (2002:78) kepuasan kerja adalah sikap umum individu terhadap pekerjaannya. Selanjutnya, perusahaan juga harus memperhatikan bagaimana menjaga dan mengelola motivasi pegawai dalam bekerja agar selalu tinggi dan fokus pada tujuan perusahaan. Menurut Robbins \& Judge (2013:236) mendefinisikan motivasi sebagai proses yang memperhitungkan intensitas individu, arah dan ketekunan upaya menuju pencapaian tujuan.

\section{RUMUSAN MASALAH}

1. Bagaimana Peran Efektivitas Komunikasi terhadap Kinerja Karyawan PT. SUCOFINDO (Persero) Cabang Pontianak?

2. Bagaimana Peran Efektivitas Komunikasi terhadap Motivasi Karyawan PT. SUCOFINDO (Persero) Cabang Pontianak?

3. Bagaimana Peran Kepuasan Kerja terhadap Kinerja Karyawan PT. SUCOFINDO (Persero) Cabang Pontianak?

4. Bagaimana Kepuasan Kerja terhadap Motivasi Karyawan PT. SUCOFINDO (Persero) Cabang Pontianak?

5. Bagaimana Peran Motivasi terhadap Kinerja Karyawan PT. SUCOFINDO (Persero) Cabang Pontianak?

6. Bagaimana Peran Efektivitas Komunikasi terhadap Kinerja Karyawan melalui Motivasi Karyawan PT. SUCOFINDO (Persero) Cabang Pontianak?

7. Bagaimana Peran Kepuasan Kerja terhadap Kinerja Karyawan melalui Motivasi Karyawan PT. SUCOFINDO (Persero) Cabang Pontianak?

\section{TINJAUAN PUSTAKA}

\section{Pengertian Manajemen Sumber Daya Manusia}

Manajemen sumber daya manusia (MSDM) merupakan salah satu bidang dari manajemen umum yang meliputi segi-segi perencanaan, pengorganisasian, pelaksanaan dan pengendalian. Proses ini terdapat dalam fungsi/bidang produksi, pemasaran, keuangan, maupun kekaryawanan. Karena sumber daya manusia (SDM) dianggap semakin penting peranannya dalam pencapaian tujuan perusahaan, maka berbagai pengalaman dan hasil penelitian dalam bidang SDM dikumpulkan secara sistematis dalam apa yang disebut manajemen sumber daya manusia. Istilah "manajemen" mempunyai arti sebagai kumpulan pengetahuan tentang bagaimana mengelola sumber daya manusia.

Simamora (2006:4) mengemukakan bahwa manajemen sumber daya manusia adalah merupakan pendayagunaan, pengembangan, penilaian, pemberian balas jasa, dan pengelolaan individu anggota organisasi atau kelompok karyawan. Sedangkan Martoyo (2007:3) mengemukakan pengertian manajemen sumber daya manusia adalah bekerja dengan orang-orang untuk menentukan, mengintepretasikan, dan 
Peran Efektivitas Komunikasi dan Kepuasan Kerja Terhadap Kinerja Dengan Motivasi Sebagai Variabel Mediasi Pada Karyawan PT. SUCOFINDO (Persero) Cabang Pontianak

Thirza Ardisha a

mencapai tujuan-tujuan organisasi dengan pelaksanaan fungsi-fungsi perencanaan (planning), pengorganisasian (organizing), penyusunan personalia/kekaryawanan (staffing), pengarahan dan kepemimpinan (leading), dan pengawasan (controlling).

\section{Komunikasi}

Sebagaimana layaknya ilmu sosial lainnya, komunikasi mempunyai banyak definisi sesuai dengan pendapat para ahli komunikasi yang memberikan batasan pengertian. Menurut kamus besar bahasa Indonesia (2007: 585) "komunikasi merupakan pengiriman dan penerimaan pesan atau berita antara dua orang atau lebih sehingga pesan yang dimaksudkan dapat dipahami." Secara etimologis, istilah komunikasi dalam bahasa Inggris "communications."

Tujuan dari komunikasi adalah merubah perilaku, komunikasi juga dikatakan sebagai transaksi mengenai informasi, gagasan, ide, simbol, pesan baik secara tersirat maupun tersurat, dan pesan tersebut tidak muncul dengan sendirinya, namun dibuat serta dikirmkan oleh komunikator atau informasi kepada komunikan atau penerima pesan.

Rogers yang dikutip oleh Suranto (2005:15) menyatakan bahwa "komunikasi ialah proses yang didalamnya terdapat suatu gagasan yang dikirimkan dari sumber kepada penerima dengan tujuan untuk merubah perilaku".

Sementara Effendi (1986: 5) mengemukakan bahwa "komunikasi adalah proses penyampaian suatu pesan oleh seseorang kepada orang lain untuk memberi tahu atau mengubah sikap, pendapat atau perilaku baik langsung secara lisan, maupun tidak langsung melalui media".

Berdasarkan beberapa pendapat tersebut dapat disimpulkan bahwa komunikasi merupakan proses pesan dari komunikator kepada komunikan atau pengiriman pesan dari satu pihak kepada pihak lain untuk mendapatkan saling pengertian.

\section{Kepuasan Kerja}

Kepuasan kerja adalah sikap seseorang terhadap pekerjaan yang dijalani. Menurut Robbins (2002: 78) kepuasan kerja merupakan sikap umum seorang pekerja terhadap pekerjaannya yang menunjukkan perbedaan antara jumlah penghargaan yang diterima pekerja dengan jumlah imbalan yang mereka yakini akan diterima.

Pada kenyataannya, dari segi kepuasan kerja (kerja itu sendiri, bayaran, kenaikan jabatan, pengawasan dan rekan kerja), menikmati kerja merupakan hal yang paling berkaitan dengan tingkat kepuasan kerja yang tinggi secara keseluruhan. Pekerjaan yang diimbangi dengan baik mempunyai tingkat kepuasan rata-rata yang tidak lebih tinggl.

\section{Kinerja}


Peran Efektivitas Komunikasi dan Kepuasan Kerja Terhadap Kinerja Dengan Motivasi Sebagai Variabel Mediasi Pada Karyawan PT. SUCOFINDO (Persero) Cabang Pontianak

Thirza Ardisha a

Perusahaan harus memiliki SDM yang berkompeten dan memiliki tingkat kinerja yang tinggi dalam menjalankan tugas-tugas yang dibebankan oleh organisasi. Kinerja karyawan dalam periode waktu tertenu perlu dievaluasi atau di nilai karena peniliaian terhadap kinerja karyawan merupakan bagian dari proses staffing, yang dimulai dari proses rekrutmen, seleksi, orientasi, penempatan, pelatihan dan proses penilaian kerja (Alwi, 2001: 177). Kenyataan dewasa ini menunjukan masih relatif banyak organisasi atau perusahaan mangabaikan fungsi penilaian terhadap kinerja. Padahal penilaian kinerja merupakan bagian yang sangat penting dari manajemen kinerja dan mungkin juga sistem penilaian yang diterapkan tidak sesuai dengan kultur oranisasi yang dikembangkan sehingga tidak mendorong motivasi kerja.

\section{Motivasi}

Robbins \& Judge (2013:236) mendefinisikan motivasi sebagai proses yang memperhitungkan intensitas individu, arah dan ketekunan upaya menuju pencapaian tujuan. Motivasi terbentuk dari sikap (attitude) karyawan dalam menghadapi situasi kerja di perusahaan (Mangkunegara, 2005:61). Motivasi dapat mendorong seseorang untuk melakukan tindakan atau tidak baik secara internal maupun eksternal yang dapat berdampak positif maupun negatif untuk mengarahkannya bergantung kepada ketangguhan manajer (Ardana, Mujiati dan Utama, 2012: 193). Motivasi timbul karena adanya suatu dorongan dan keinginan dalam diri masing-masing individu.

\section{KERANGKA KONSEPTUAL PENELITIAN}

Berdasarkan latar belakang, landasan teori, dan penelitian terdahulu yang telah dijelaskan sebelumnya maka dapat disusun kerangka konseptual penelitian sebagai berikut :

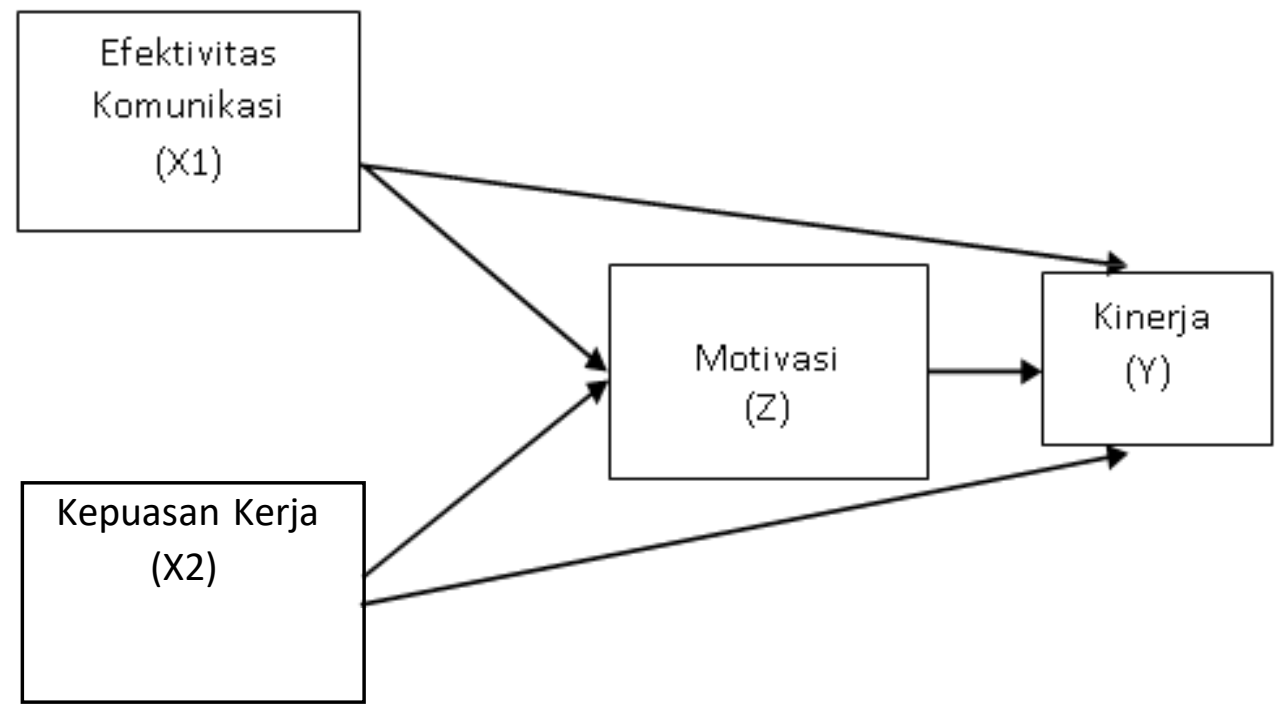

Gambar Kerangka Konseptual Penelitian

H1: Terdapat pengaruh yang signifikan antara Efektivitas Komunikasi terhadap Kinerja Karyawan PT. SUCOFINDO (Persero) Cabang Pontianak.

*corresponding authors e-mail : thirzaardishatz@gmail.com Online ISSN: 2721-4230 | Print ISSN: 2721-4281 DOI : http://dx.doi.org/10.26418/ejme.v8i3.43640 
Peran Efektivitas Komunikasi dan Kepuasan Kerja Terhadap Kinerja Dengan Motivasi Sebagai Variabel Mediasi Pada Karyawan PT. SUCOFINDO (Persero) Cabang Pontianak

Thirza Ardisha a

H2: Terdapat pengaruh yang signifikan antara Efektivitas Komunikasi terhadap Motivasi Karyawan PT. SUCOFINDO (Persero) Cabang Pontianak.

H3: Terdapat pengaruh yang signifikan antara Kepuasan Kerja terhadap Kinerja Karyawan PT. SUCOFINDO (Persero) Cabang Pontianak.

H4: Terdapat pengaruh yang signifikan antara Kepuasan Kerja terhadap Motivasi Karyawan PT. SUCOFINDO (Persero) Cabang Pontianak.

H5: Terdapat pengaruh yang signifikan antara Motivasi terhadap Kinerja Karyawan PT. SUCOFINDO (Persero) Cabang Pontianak.

H6: Terdapat pengaruh yang signifikan antara Efektivitas Komunikasi terhadap Kinerja Karyawan melalui Motivasi Karyawan PT. SUCOFINDO (Persero) Cabang Pontianak.

H7: Terdapat pengaruh yang signifikan antara Kepuasan Kerja terhadap Kinerja Karyawan melalui Motivasi Karyawan PT. SUCOFINDO (Persero) Cabang Pontianak.

\section{METODE PENELITIAN}

\section{Bentuk Penelitian}

Penelitian ini adalah penelitian deskriptif asosiatif. Menurut Sugiyono (2016) adalah penelitian yang bertujuan untuk mengetahui pengaruh ataupun juga hubungan antara dua variabel atau lebih. Dalam penelitian ini, bentuk penelitian asosiatif digunakan untuk mengetahui Peran Efektivitas Komunikasi dan Kepuasan Kerja terhadap Kinerja dengan Motivasi sebagai Variabel Mediasi di PT. SUCOFINDO (Persero) Cabang Pontianak.

Selain itu, penelitian yang dilakukan ini bersifat Cross-Sectional, yaitu penelitian yang dilakukan dalam waktu tertentu yang relatif pendek dan tempat tertentu. Pendekatan penelitian menggunakan pendekatan kuantitatif dimana penelitian ini akan menguji hipotesis yang telah dirumuskan sebelumnya dan membuat analisis perhitungan berdasarkan data yang ada serta mendeskripsikannya secara sistematis, faktual, dan akurat mengenai fakta-fakta, sifat-sifat, serta hubungan antar fenomena yang akan diselidiki.

\section{Populasi dan Sampel}

Adapun karyawan PT. SUCOFINDO (Persero) Cabang Pontianak berjumlah 74 orang yang terdiri dari 20 pegawai tetap dan 54 pegawai tidak tetap sebagai populasi. Dengan demikian karena populasi yang diperoleh kurang dari 100 orang, maka dalam penelitian ini peneliti menggunakan sampel sebanyak 73 orang dengan masa kerja seluruh responden $\geqslant 3$ tahun, di luar Kepala Cabang yang tidak dijadikan sampel.

\section{Variabel Penelitian}

1. Variabel bebas (independent variabel) yang dilambangkan dengan (X), yaitu variabel yang mempengaruhi yang terdiri dari dua variabel bebas yaitu Efektivitas Komunikasi (X1) dan Kepuasan kerja (X2). 
Peran Efektivitas Komunikasi dan Kepuasan Kerja Terhadap Kinerja Dengan Motivasi Sebagai Variabel Mediasi Pada Karyawan PT. SUCOFINDO (Persero) Cabang Pontianak

Thirza Ardisha a

2. Variabel mediasi atau perantara yang dilambangkan dengan (Z), yaitu variabel yang menghubungkan pengaruh antara variabel dependen dengan variabel independen. Dalam penelitian ini adalah Motivasi sebagai variabel mediasi.

3. Variabel terikat (dependent variabel) yang dilambangkan dengan (Y), yaitu variabel yang dipengaruhi atau menjadi akibat karena adanya variabel bebas. Dalam penelitian ini Kinerja sebagai variabel terikat.

\section{Metode Analisis Data}

Teknik analisis data dilakukan dengan menggunakan analisis jalur (path analysis) melalui software SPSS 23. Skala penelitian menggunakan skala likert dengan evaluasi model pengukuran uji validitas dan reliabilitas, uji asumsi klasik yang terdiri dari uji normalitas, linearitas, multikolinearitas, dan heteroskedastisitas. Dalam hal ini uji model struktural menggunakan analisis jalur (path analysis) untuk mengetahui seberapa besar pengaruh antar variabel dan nilai signifikansinya, serta uji beda untuk mengevaluasi perlakuan (treatment) tertentu pada satu sampel yang sama pada dua periode yang berbeda.

\section{HASIL DAN PEMBAHASAN}

\section{Hasil Analisis Statistik Deskriptif}

Berdasarkan tanggapan responden pada variabel komunikasi memiliki nilai rata-rata 4, 11 (baik), variabel kepuasan kerja dengan nilai rata-rata 3,97 (baik), variabel kinerja dengan nilai rata-rata 4,06 (baik), dan variabel motivasi dengan rata-rata 3,92 (baik).

\section{Uji Validitas Variabel}

\section{Komunikasi}

\begin{tabular}{|c|c|c|c|}
\hline Item Pertanyaan & Korelasi & Nilai Batas & Kesimpulan \\
\hline X11 & 0,539 & 0,3 & Valid \\
\hline X12 & 0,625 & 0,3 & Valid \\
\hline X13 & 0,602 & 0,3 & Valid \\
\hline X14 & 0,605 & 0,3 & Valid \\
\hline X15 & 0,727 & 0,3 & Valid \\
\hline X16 & 0,544 & 0,3 & Valid \\
\hline X17 & 0,655 & 0,3 & Valid \\
\hline X18 & 0,618 & 0,3 & Valid \\
\hline X19 & 0,569 & 0,3 & Valid \\
\hline X110 & 0,569 & 0,3 & Valid \\
\hline X111 & 0,569 & 0,3 & Valid \\
\hline
\end{tabular}

Sumber : SPSS 23, data diolah 2020 
Peran Efektivitas Komunikasi dan Kepuasan Kerja Terhadap Kinerja Dengan Motivasi Sebagai Variabel Mediasi Pada Karyawan PT. SUCOFINDO (Persero) Cabang Pontianak

Thirza Ardisha a

Hasil pengujian valitas item kuesioner menunjukkan bahwa seluruh item pernyataan dalam setiap Variabel (XI) memiliki nilai korelasi di atas 0,3 sebagai nilai batas suatu item kuesioner penelitian dikatakan dapat digunakan (dapat diterima). Sehingga dapat dikatakan bahwa item angket Variabel Komunikasi (XI) valid dan dapat digunakan untuk mengukur variabel yang diteliti.

Kepuasan Kerja

\begin{tabular}{|c|c|c|c|}
\hline Item Pertanyaan & Korelasi & Nilai Batas & Kesimpulan \\
\hline X21 & 0,491 & 0,3 & Valid \\
\hline X22 & 0,537 & 0,3 & Valid \\
\hline X23 & 0,735 & 0,3 & Valid \\
\hline X24 & 0,748 & 0,3 & Valid \\
\hline X25 & 0,748 & 0,3 & Valid \\
\hline X26 & 0,656 & 0,3 & Valid \\
\hline X27 & 0,713 & 0,3 & Valid \\
\hline X28 & 0,750 & 0,3 & Valid \\
\hline X29 & 0,758 & 0,3 & Valid \\
\hline X210 & 0,553 & 0,3 & Valid \\
\hline X211 & 0,502 & 0,3 & Valid \\
\hline X212 & 0,369 & 0,3 & Valid \\
\hline X213 & 0,309 & 0,3 & Valid \\
\hline X214 & 0,334 & 0,3 & Valid \\
\hline X215 & 0,413 & 0,3 & Valid \\
\hline
\end{tabular}

Sumber : SPSS 23, data diolah 2020

Hasil pengujian valitas item kuesioner menunjukkan bahwa seluruh item pernyataan dalam setiap Variabel (Y) memiliki nilai korelasi di atas 0,3 sebagai nilai batas suatu item kuesioner penelitian dikatakan dapat digunakan (dapat diterima). Sehingga dapat dikatakan bahwa item angket Variabel Kinerja (Y) valid dan dapat digunakan untuk mengukur variabel yang diteliti.

\section{Motivasi}

\begin{tabular}{|c|c|c|c|}
\hline Item Pertanyaan & Korelasi & Nilai Batas & Kesimpulan \\
\hline Z1 & 0,700 & 0,3 & Valid \\
\hline Z2 & 0,758 & 0,3 & Valid \\
\hline Z3 & 0,790 & 0,3 & Valid \\
\hline Z4 & 0,746 & 0,3 & Valid \\
\hline Z5 & 0,645 & 0,3 & Valid \\
\hline Z6 & 0,791 & 0,3 & Valid \\
\hline Z7 & 0,627 & 0,3 & Valid \\
\hline Z8 & 0,641 & 0,3 & Valid \\
\hline Z9 & 0,700 & 0,3 & Valid \\
\hline
\end{tabular}

Sumber : SPSS 23, data diolah 2020 
Peran Efektivitas Komunikasi dan Kepuasan Kerja Terhadap Kinerja Dengan Motivasi Sebagai Variabel Mediasi Pada Karyawan PT. SUCOFINDO (Persero) Cabang Pontianak

Thirza Ardisha a

Hasil pengujian valitas item kuesioner menunjukkan bahwa seluruh item pernyataan dalam setiap Variabel (Z) memiliki nilai korelasi di atas 0,3 sebagai nilai batas suatu item kuesioner penelitian dikatakan dapat digunakan (dapat diterima). Sehingga dapat dikatakan bahwa item angket Variabel Motivasi (Z) valid dan dapat digunakan untuk mengukur variabel yang diteliti.

\section{Uji Reliabilitas Variabel}

Komunikasi

Sumber : SPSS 23, data diolah 2020

\begin{tabular}{|c|c|}
\hline Cronbach's Alpha & N of Items \\
\hline 0,823 & 11 \\
\hline
\end{tabular}

Berdasarkan hasil uji reliabilitas diperoleh hasil perhitungan menunjukkan nilai Cronbach's Alpha sebesar 0,823 lebih besar dari 0,700. Artinya data yang dipergunakan dalam penelitian ini reliabel atau dapat dipercaya sehingga dapat dilanjutkan pada analisis berikutnya.

Kepuasan Kerja

\begin{tabular}{|c|c|}
\hline Cronbach's Alpha & N of Items \\
\hline 0,863 & 15 \\
\hline
\end{tabular}

Sumber : SPSS 23, data diolah 2020

Berdasarkan hasil uji reliabilitas diperoleh hasil perhitungan menunjukkan nilai Cronbach's Alpha sebesar 0,863 lebih besar dari 0,700. Artinya data yang dipergunakan dalam penelitian ini reliabel atau dapat dipercaya sehingga dapat dilanjutkan pada analisis berikutnya.

Kinerja

Sumber : SPSS 23, data diolah 2020

\begin{tabular}{|c|c|}
\hline Cronbach's Alpha & N of Items \\
\hline 0,919 & 12 \\
\hline
\end{tabular}

Berdasarkan hasil uji reliabilitas diperoleh hasil perhitungan menunjukkan nilai Cronbach's Alpha sebesar 0,919 lebih besar dari 0,700. Artinya data yang dipergunakan dalam penelitian ini reliabel atau dapat dipercaya sehingga dapat dilanjutkan pada analisis berikutnya.

Motivasi

\begin{tabular}{|c|c|}
\hline Cronbach's Alpha & N of Items \\
\hline 0,876 & 9 \\
\hline
\end{tabular}

Sumber : SPSS 23, data diolah 2020 
Peran Efektivitas Komunikasi dan Kepuasan Kerja Terhadap Kinerja Dengan Motivasi Sebagai Variabel Mediasi Pada Karyawan PT. SUCOFINDO (Persero) Cabang Pontianak

Thirza Ardisha a

Berdasarkan hasil uji reliabilitas diperoleh hasil perhitungan menunjukkan nilai Cronbach's Alpha sebesar 0,876 lebih besar dari 0,700. Artinya data yang dipergunakan dalam penelitian ini reliabel atau dapat dipercaya sehingga dapat dilanjutkan pada analisis berikutnya.

\section{Uji Asumsi Klasik}

Hasil Uji Normalitas dengan Uji One Sample Kolmogorov-Smirnov

\begin{tabular}{|c|c|}
\hline $\mathbf{N}$ & Asymp. Sig. (2-tailed) \\
\hline 73 & 0.200 \\
\hline
\end{tabular}

Ringkasan Hasil Uji Linieritas

\begin{tabular}{|c|c|c|}
\hline Linieritas & F & Sig \\
\hline $\mathbf{Y} * \mathbf{X 1}$ : Deviation from Linearity & 0,891 & 0,578 \\
\hline $\mathbf{Y}$ X2 : Deviation from Linearity & 0,630 & 0,871 \\
\hline $\begin{array}{l}\mathbf{Y} \mathbf{Z}: \text { Deviation from } \\
\text { Linearity }\end{array}$ & 1,062 & 0,411 \\
\hline
\end{tabular}

Ringkasan Hasil Uji Heterokedastisitas Melalui Uji Glejser

\begin{tabular}{|c|c|c|c|}
\hline Model & B & Std. Error & Sig \\
\hline $\mathrm{X} 1$ & $-0,073$ & 0,147 & 0,622 \\
\hline $\mathrm{X} 2$ & $-0,021$ & 0,101 & 0,839 \\
\hline $\mathrm{Z}$ & 0,260 & 0,132 & 0,053 \\
\hline
\end{tabular}

Ringkasan Hasil Uji Multikolinieritas

\begin{tabular}{|c|c|c|}
\hline Model & Tolerance & VIF \\
\hline $\mathrm{X} 1$ & 0,683 & 1,464 \\
\hline $\mathrm{X} 2$ & 0,590 & 1,694 \\
\hline $\mathrm{Z}$ & 0,612 & 1,635 \\
\hline \multicolumn{2}{|l}{} \\
\hline
\end{tabular}




\section{Pengujian Hipotesis}

Analisis Regresi Model 1

Pengujian U ji Parsial

\begin{tabular}{|c|c|c|c|c|}
\hline Model & B & Standardized Coefficients & T & Sig \\
\hline $\mathrm{X} 1$ & 0,298 & 0,254 & 2.334 & 0,022 \\
\hline $\mathrm{X} 2$ & 0,342 & 0,453 & 4,159 & 0,00 \\
\hline Variabel dependen : Z \\
\hline
\end{tabular}

Koefisien Determinasi

\begin{tabular}{|c|c|c|c|c|}
\hline Model & R & R Square & $\begin{array}{c}\text { Adjusted R } \\
\text { Square }\end{array}$ & $\begin{array}{c}\text { Std. E rror of the } \\
\text { Estimate }\end{array}$ \\
\hline 1 & 0,623 & 0,388 & 0,371 & 3.49636 \\
\hline \multicolumn{2}{l}{ Predictors : X2 dan X1 } \\
\hline
\end{tabular}

Ringkasan Hasil Uji F Regresi Linear Berganda

\begin{tabular}{|c|c|c|c|}
\hline Model & Mean Square & F & Sig \\
\hline Regresi & 271.622 & 22.219 & 0,000 \\
\hline Residual & 12,224 & - & - \\
\hline Predictor X2, X1 \\
\hline
\end{tabular}

\section{Analisis Regresi Model 2}

Ringkasan Hasil Pengujian Uji Parsial

\begin{tabular}{|c|c|c|c|c|}
\hline Model & B & Standardized Coefficients & t & Sig \\
\hline $\mathrm{X} 1$ & 0,495 & 0,303 & 2,666 & 0,010 \\
\hline $\mathrm{X} 2$ & 0,243 & 0,284 & 2,520 & 0,014 \\
\hline $\mathrm{Z}$ & 0,133 & 0,220 & 2,014 & 0,048 \\
\hline \multicolumn{5}{|r|}{ Variabel Dependent : Y } \\
\hline
\end{tabular}

Koefisien Determinasi

\begin{tabular}{|c|c|c|c|c|}
\hline Model & R & R Square & $\begin{array}{c}\text { Adjusted R } \\
\text { Square }\end{array}$ & $\begin{array}{c}\text { Std. Error of } \\
\text { the Estimate }\end{array}$ \\
\hline $\mathbf{1}$ & 0,446 & 0,199 & 0,164 & 5,40949 \\
\hline \multicolumn{5}{|c|}{ Predictors : X2, X1, Z } \\
\hline
\end{tabular}


Ringkasan Hasil Uji F Regresi Linear Berganda

\begin{tabular}{|c|c|c|c|}
\hline Model & Mean Square & F & Sig \\
\hline Regresi & 167.308 & 5,717 & 0,001 \\
\hline $\begin{array}{c}\text { Residua } \\
1\end{array}$ & 29.263 & - & - \\
\hline Predictor X2, X1, Z \\
\hline
\end{tabular}

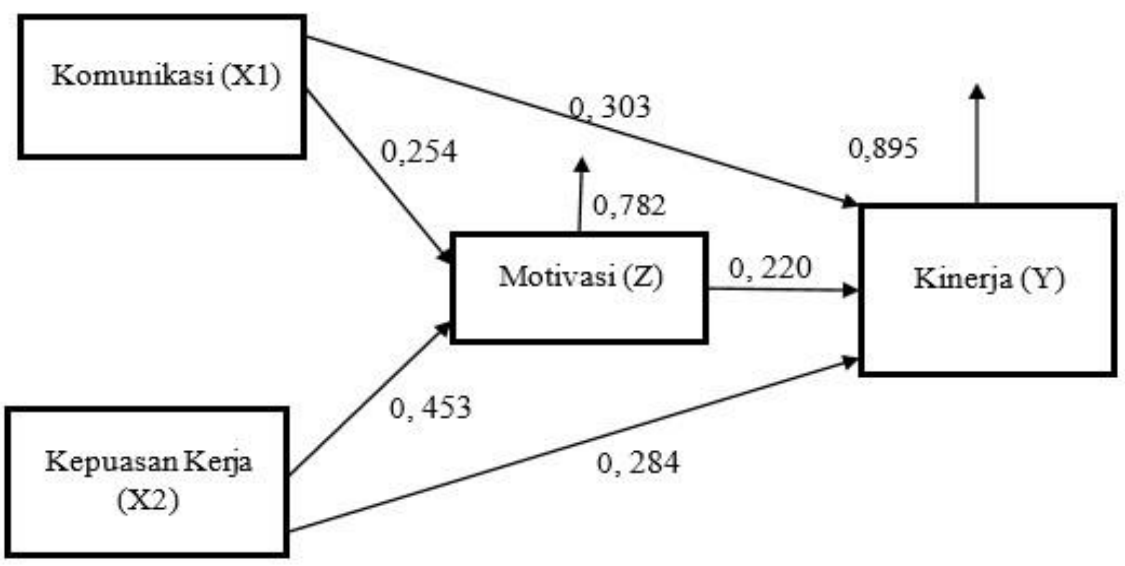

Gambar: Komunikasi (X1), Kepuasan Kerja (X2), Motivasi (Z) terhadap Kinerja (Y)

Ringkasan hasil Regregsi

\begin{tabular}{|c|c|c|c|c|}
\hline Model 2 & B & Standardized Coefficients & t & Sig \\
\hline Constant & 35.476 & 0 & 4,011 & 0,000 \\
\hline X1 & 0,495 & 0,303 & 2,666 & 0,010 \\
\hline X2 & 0,243 & 0,284 & 2,520 & 0,014 \\
\hline Z & 0,133 & 0,220 & 2,014 & 0,048 \\
\hline \multicolumn{4}{|l}{ Variabel Dependent : Y }
\end{tabular}

Dari tabel regresi menunjukkan bahwa nilai koefisien regresi komunikasi sebesar 0,303 dengan standar eror 0,186 dan nilai signifikansi 0,010, kemudian untuk kepuasan kerja mendapatkan nilai koefisien 0,284 dengan standar eror 0,096 dan nilai signifikansi 0,014. Selain itu motivasi mendapatkan nilai koefisien 0,220 dengan standar eror 0,066 dan nilai signifikansi 0,048. Sehingga komunikasi signifikan berpengaruh langsung terhadap kinerja pegawai, kepuasan kerja signifikan berpengaruh langsung terhadap kinerja pegawai. Demikian juga motivasi signifikan berpengaruh langsung terhadap kinerja pegawai. Seperti yang digambarkan pada model diatas. 
Ringkasan Pengaruh Langsung Tidak Langsung

\begin{tabular}{|c|c|c|c|c|}
\hline Variabel & $\mathbf{Z}$ & $\mathbf{t}$ & Kesimpulan & Sig \\
\hline Komunikasi & 3,622 & 1,644 & $\begin{array}{c}\text { Motivasi } \\
\text { sebagai } \\
\text { Mediasi }\end{array}$ & 0,010 \\
\hline $\begin{array}{c}\text { Kepuasan } \\
\text { Kerja }\end{array}$ & 3,622 & 1,644 & $\begin{array}{c}\text { Motivasi } \\
\text { sebagai } \\
\text { Mediasi }\end{array}$ & 0,014 \\
\hline
\end{tabular}

Sumber : SPSS 23, data diolah 2020

Analisis Uji Beda

Paired Samples Test

\begin{tabular}{|l|c|l|c|c|}
\hline TETAP - & Mean & Std. Deviation & $\mathrm{T}$ & Sig \\
\cline { 2 - 5 } TIDAKTETAP & -5.05556 & 17.93153 & -1.692 & .100 \\
\hline
\end{tabular}

\section{Kesimpulan}

Penelitian ini dilakukan untuk mengetahui seberapa besar pengaruh Efektivitas Komunikasi (X1), Kepuasan Kerja (X2) terhadap Kinerja (Y) Karyawan dengan Motivasi (Z) sebagai varibel mediasi Pada PT. SUCOFINDO (Persero) Cabang Pontianak. Berdasarkan hasil penelitian dan pembahasan pada bab sebelumnya, maka kesimpulan yang dapat diambil adalah sebagai berikut:

1. Variabel Efektivitas Komunikasi berpengaruh siginifikan terhadap Kinerja Karyawan. Hal ini juga dapat dibuktikan dengan tanggapan responden terhadap variabel efektivitas komunikasi dengan memberikan kriteria sangat baik pada item pertanyaan nomor satu dengan nilai rata-rata sebesar 4,21 dan item pertanyaan nomor tiga dengan nilai rata-rata sebesar 4,22. Sedangkan variabel kinerja memberikan kriteria sangat baik pada item pertanyaan nomor satu dengan nilai rata-rata sebesar 4,30.

2. Variabel Efektivitas Komunikasi berpengaruh siginifikan terhadap Motivasi. Hal ini juga dapat dibuktikan dengan tanggapan responden terhadap variabel efektivitas komunikasi dengan memberikan kriteria sangat baik pada item pertanyaan nomor satu dengan nilai rata-rata sebesar 4,21 dan nomor tiga dengan nilai rata-rata sebesar 4,22. Sedangkan variabel motivasi memberikan kriteria baik pada item pertanyaan nomor tujuh dengan nilai rata-rata sebesar 4,11 .

3. Variabel Kepuasan Kerja berpengaruh siginifikan terhadap Kinerja Karyawan. Hal ini juga dapat dibuktikan dengan tanggapan responden terhadap variabel kepuasan kerja dengan memberikan kriteria sangat baik pada item pertanyaan 
nomor tiga belas dengan nilai rata-rata sebesar 4,45 dan item pertanyaan nomor empat belas dengan nilai rata-rata sebesar 4,30. Sedangkan variabel kinerja memberikan kriteria sangat baik pada item pertanyaan nomor satu dengan nilai rata-rata sebesar 4,30.

4. Variabel Kepuasan Kerja berpengaruh siginifikan terhadap Motivasi. Hal ini juga dapat dibuktikan dengan tanggapan responden terhadap variabel kepuasan kerja dengan memberikan kriteria sangat baik pada item pertanyaan tiga belas dengan nilai rata-rata sebesar 4,45 dan item pertanyaan nomor empat belas dengan nilai rata-rata sebesar 4,30. Sedangkan variabel motivasi memberikan kriteria baik pada item pertanyaan nomor tujuh dengan nilai rata-rata sebesar 4,11.

5. Variabel Motivasi berpengaruh siginifikan terhadap Kinerja Karyawan. Hal ini juga dapat dibuktikan dengan tanggapan responden terhadap variabel motivasi dengan memberikan kriteria baik pada item pertanyaan nomor tujuh dengan nilai rata-rata sebesar 4,11. Sedangkan variabel kinerja memberikan kriteria sangat baik pada item pertanyaan nomor satu dengan nilai rata-rata sebesar 4,30 .

6. Secara statistik pengaruh langsung Efektivitas Komunikasi terhadap kinerja karyawan lebih kecil dibandingkan dengan pengaruh tidak langsung melalui variabel mediasi yaitu Motivasi. Ini artinya Motivasi berhasil menjadi mediasi.

7. Secara statistik pengaruh langsung Kepuasan Kerja terhadap kinerja karyawan lebih kecil dibandingkan dengan pengaruh tidak langsung melalui variabel mediasi yaitu Motivasi. Ini artinya Motivasi berhasil menjadi mediasi.

\section{Rekomendasi}

Berdasarkan hasil analisis dan pembahasan, adapun saran dari peneliti adalah sebagai berikut ini :

1. Pada variabel efektivitas komunikasi masih ada karyawan yang kurang puas dengan pujian yang diberikan atasan atas keberhasil kerja mereka, karenanya perusahaan harus mampu menjalin hubungan baik antara atasan dan bawahan, adanya umpan balik, iklim komunikasi yang mendukung serta perspektif organisasi yang terarah. Selain itu perusahaan juga dapat melibat karyawan dalam bentuk komunikasi dua arah misalnya dengan menyediakan kotak saran untuk atasan.

2. Perusahaan juga bisa mempertimbangkan dan memperhatikan kepuasan kerja karyawan terkait imbalan atau gaji sebab berdasarkan tanggapan responden, karyawan belum terlalu puas dengan imbalan atau gaji yang mereka terima saat ini, karenanya penting bagi perusahaan untuk melakukan kenaikan gaji secara 
Peran Efektivitas Komunikasi dan Kepuasan Kerja Terhadap Kinerja Dengan Motivasi Sebagai Variabel Mediasi Pada Karyawan PT. SUCOFINDO (Persero) Cabang Pontianak

Thirza Ardisha a

berkala, atau pemberian bonus akhir tahun, bonus capaian, tunjangan hari raya, tunjangan hari tua.

3. Dari variabel motivasi perusahaan dapat memberikan fasilitas peningkatan hard and soft-skills seperti pelatihan-pelatihan (training) sehingga bisa lebih meningkatkan motivasi karyawan, dan karyawan merasa lebih bisa mempunyai kesempatan untuk lebih maju dan berkembang guna peningkatan kinerja dan menguntungkan bagi perusahaan.

4. Untuk penelitian di masa yang akan datang bisa memperluas objek penelitian, variabel-variabel yang diteliti seperti perilaku organisasi, iklim organisasi, iklim komunikasi, Quality of Work Life (QWL), dan lain sebagainya yang lebih dapat meningkatkan kinerja karyawan. Diharapkan penelitian selanjutnya juga bisa mengkaji lebih dalam tentang motivasi yang pada penelitian ini 


\section{DAFTAR PUSTAKA}

Abdullah, Ma'aruf. (2014). Manajemen dan Evaluasi Kinerja Karyawan.

Yogyakarta: Aswanda Pressindo.

Achmad Kuncoro, Engkos dan Ridwan. (2012). Analisis Jalur (Path Analysis) Edisikedua. Bandung: Alfabeta.

A Dale, Timpe. (1993). Kinerja. Jakarta: PT. Gramedia.

Afifah, Thara \& Al Musadieq, Mochammad. (2017). Pengaruh Kepuasan Kerja Terhadap Motivasi Kerja dan Dampaknya Terhadap Kinerja (Studi padaKaryawan PT Pertamina Geothermal Energy Kantor Pusat Jakarta). Jurnal Jurnal Administrasi Bisnis, Vol. 47 No.1

Alwi, Syafaruddin. (2001). Manajemen Sumber Daya Manusia Strategi Keunggulan Kompetitif. Yogyakarta: BPFE UGM.

Amury, Zilzaal Sefty. (2016). Pengaruh Kepuasan Kerja Pada Kinerja Pegawai Kantor Pusat Administrasi Universitas Lampung Dengan Motivasi Variabel Pemoderasi. Tesis. Bandar Lampung: Universitas Lampung.

Ardana, I Komang, I wayan Mujiati \& Wayan Mudiartha Utama. (2012). Manajemen Sumber Daya Manusia. Yogyakarta: Graha Ilmu.

Ardiansyah, Dimas Okta. (2016). Pengaruh Komunikasi terhadap Kinerja Karyawan Dengan Dimediasi Oleh Kepuasan Kerja (Studi Pada Bagian Produksi Pabrik Kertas PT. Setia Kawan Makmur Sejahtera Tulungagung). Jurnal Bisnis dan Manajemen. Vol. 3(1). hh 16-30.

Arifin, Johar. (2017). SPSS untuk penelitian dan Skripsi. Elax Media Komputindo.

Arikunto, S. (2015). Prosedur Penelitian : Suatu Pendekatan Praktik. Jakarta: Rineka Cipta.

Bandhaso, Mira Labi \& Paranoan, Natalia. (2019). Pengaruh Kepuasan Kerja dan Motivasi Kerja Terhadap Kinerja Dosen Fakultas Ekonomi di Perguruan Tinggi Swasta Makassar. Jurnal Akuntansi Netral, Akuntabel, Objektif. Vol. 1.No.2.

Bastian, Indra. (2006). Akuntansi Sektor Publik: Suatu Pengantar. Jakarta: Erlangga.

Bernardin, H. John, dan Joyce E.A Russel. (2003). Human resource management (An Experimental Approach International Edition). Mc. Graw-Hill Inc. Singapore. 
Chowdury, Mohammed, S. (2007). Enhancing Motivation and Work Performanceof the salespeople: The impact of Supervisors' Behavior. New York: The International Journal of Applied Management and Technology, Vol. 6, Num 1

Colquitt, Lepine \& Wesson. (2013). Organizational Behavior. Mc Graw-Hill Irwin.Daft,

Richard L. (2000). Manajemen. Jakarta: Erlangga.

Deddy Mulyana. (2005). Ilmu Komunikasi Suatu Pengantar. Bandung: PT Ramaja Rosdakarya.

Depdikbud. (2007). Kamus Besar Bahasa Indonesia. Jakarta: Balai Pustaka. KamusBesar Bahasa Indonesia.

De Vito, Joseph H. (2004). Komunikasi Antar Manusia Edisi Kelima. Jakarta: Professional Books.

Dokumen PT.SUCOFINDO (Persero) Cabang Pontianak.

Erni, Tisnawati Sule \& Kurniawan Saefullah. (2005). Pengantar Manajemen Edisi Pertama. Jakarta: Prenada Media.

Ghozali, Imam. (2011). Aplikasi Analisis Multivariat Dengan Program SPSS.Semarang : Badan Penerbit Universitas Diponegoro.

Ghozali, Imam. (2013). Aplikasi Analisis Multivariat Dengan Program SPSS.Semarang : Badan Penerbit Universitas Diponegoro.

Ghozali, Imam. (2016). Aplikasi Analisis Multivariat Dengan Program SPSS.Semarang : Badan Penerbit Universitas Diponegoro.

Guo, Yun., Liao, Jianqiao., Liao, Shudi., Zhang, Yanhong. (2014). The Mediating Role of Intrinsic Motivation on The Relationship Between Developmental Feedback and Employee Job Performance. Huangzhong University of science and technology. 
Handoko, T. H. (2001). Manajemen, edisi 2. Yogyakarta: BPFE.

Hasibuan, H. Malayu S.P. (2003). Organisasi \& Motivasi. Jakarta: PT Bumi Aksara

Hasibuan, Malayu S. P. (2003). Manajemen, Dasar, Pengertian, Dan Masalah Edisi Revisi. Jakarta: PT. Bumi Aksara.

Hasibuan, Malayu S. P. (2008). Manajemen, Dasar, Pengertian, Dan Masalah Edisi Revisi. Jakarta: PT. Bumi Aksara.

Hasibuan, Malayu. S.P. (2009). Manajemen Sumber Daya Manusia. Edisi Revisi. Jakarta: Bumi Aksara.

Hermawan.A, Yusran. H.L. (2017). Penelitian Bisnis Pendekatan Kuantitatif. Kencana.

Indrarini. (2009). Pengaruh Motivasi dan Kepuasan Kerja Terhadap Kinerja Dosen Akademi Swasta di Kota Semarang. Tesis, Program Pascasarjana Program Studi Manajemen Pendidikan Universitas Negeri Semarang.

Indrasari, Meithiana. (2017). Kepuasan Kerja dan Kinerja Karyawan Tinjauan dari Dimensi Iklim Organisasi, Kreativitas Individu, dan Karakteristik Pekerjaan. Sidoarjo: Indomedia Pustaka.

Irwanto, Oryza Astavidha. (2015). Pengaruh Kepuasan Komunikasi Downward Terhadap Kinerja Karyawan dengan Motivasi Intrinsik Sebagai Variabel Mediasi.Tesis. Yogyakarta: Universitas Atma Jaya.

Ivancevich. (2009). Perilaku dan Manajemen Organisasi Edisi ketujuh Jilid 2.

Jakarta: Erlangga.

Jonika, Eligia Dessyani. (2016). Peran Motivasi Sebagai Variabel Intervening Pada Pengaruh Gaya Kepemimpinan Terhadap Prestasi Kerja studi kasus: karyawantetap dari semua unit/bagian Hotel Jentra Dagen Yogyakarta. Skripsi thesis, Sanata Dharma University.

Kadarisman, M. (2012). Manajemen Pengembangan Sumber Daya Manusia.

Jakarta: Rajawali Pers. 
Kotler, Amstrong. (2001). Prinsip-prinsip pemasaran, Edisi keduabelas, Jilid 1. Jakarta: Erlangga.

Kuswadi. (2005). Cara Mengukur Kepuasan Karyawan. Jakarta: PT Elex Media Komputindo.

Mangkunegara, Anwar Prabu. (2005). Perilaku dan Budaya Organisasi. Cetakan Pertama. Bandung: Remaja Rosda Karya.

Mangkunegara, Anwar Prabu. (2005). Evaluasi Kinerja SDM. Bandung: Refika Aditama.

Mangkunegara, Anwar Prabu. (2008). Perencanaan dan Pengembangan Sumber Daya Manusia. Edisi kedua. Cetakan ketiga. Bandung: Refika Aditama.

Mangkunegara, Anwar Prabu. (2013). Manajemen Sumber Daya Manusia Perusahaan. Bandung: PT Remaja Rosda Karya.

Mangkunegara, Anwar Prabu. (2016). Manajemen Sumber Daya Manusia Perusahaan. Bandung: PT Remaja Rosda Karya.

Martoyo, Susilo. (2007). Manajemen Sumber Daya Manusia, Edisi 5, Cetakan Pertama. Yogyakarta: BPFE.

Mathis, Robert. L.,\& John H. Jackson. (2006). Manajemen Sumber Daya ManusiaEdisi Sepuluh. Jakarta: Salemba Empat.

Mc. Clelland, David C. (1961). The Achieving Society. New York: D. Van Nostrand Company, Inc.

Moekijat. (2002). Dasar-Dasar Motivasi. Bandung: Pionir Jaya.

Mpungu, Bbosa Musa, (2009). The Effect of Communication on Workers' Performance in Organizations: A Case of Mobile Telephone Network (MTN) Kampala. Journal of Productivty and Perfomance Management. Harvard Business Review

Mulyana, Deddy. (2005). Ilmu Komunikasi Suatu Pengantar. Bandung: PT Remaja Rosdakarya 
Olusola, Olayiwola. (2011). Intrinsic Motivation, Job Satisfaction And Self- Efficacy as Predictors of Job Performance of Industrial Workers in Ijebu Zoneof Ogun State: The Journal of International Social Research.

Onong Uchana Effendy. (2003). Ilmu Komunikasi (Teori dan Praktek). Bandung: PT Remaja Rosdakarya.

Pratiwi, Rizka Novrianti. (2019). Peran Efektivitas Komunikasi dan Pemberian Reward Terhadap Kepercayaan dan Kinerja Karyawan CV Prima Rizki Coorporation.Tesis. Pontianak: Universitas Tanjungpura.

Prokopenko, Joseph. (1987). Productivity Management: A Practical Handbook. Geneva: International Labour Organization.

Robbins, Stephen. P. (2002). Prinsip-Prinsip Perilaku Organisasi. Edisi 5. Jakarta: Erlangga.

Robbins, Stephen. P. (2006). Perilaku Organisasi Edisi Lengkap, Edisi Kesepuluh. Jakarta: Indeks.

Robbins, Stephen. P., \& Timothy A.Judge. (2007). Organizational behavior (12th ed.). Upper Saddle River, NJ: Pearson Prentice Hall.

Robbins, Stephen. P., \& Timothy A.Judge. (2013). Organizational behavior. United States: Pearson Education Limited.

Robbins, Stephen. P., \& Timothy A.Judge. (2014). Perilaku Organisasi Buku Edisi 12. Jakarta: Salemba Empat.

Robbins, Stephen. P \& Judge, Timothy.A. (2017). Perilaku Organisasi Edisi EnamBelas. Jakarta: Salemba Empat.

Rohadi. (2005). Pengaruh Motivasi, Kepuasan Kerja, dan Komitmen Organisasi pada Kinerja Guru pada Kinerja Guru Bantu SMA di Kabupaten Kendal. Tesis. Semarang: PPs Universitas Negeri Semarang.

Sarido \& Euis Soliha. (2016). Pengaruh Komunikasi Dan Kompensasi Terhadap Kinerja Pegawai Dengan Motivasi Dan Komitmen Organisasional Sebagai Mediasi (Studi Pada Kantor Badan Kepegawaian Daerah Provinsi JawaTengah). Vol 13 No 2 (2016): Vol. 13 No. 22016. 
Setiawan, A.D (2016). Pengaruh Komunikasi Terhadap Kinerja Karyawan Pada PT. Karya Subur Tekhnik Utama Di Kota Makassar. Jurnal Ekonomi Vokasi Vol.2 No.2

Setiawan, Singgih \& Mulyapradana, Aria. (2019). Peran Work Motivation Sebagai Variabel Intervening Pengaruh Instrinsic Reward, Supervision Of Work \& Statisfaction Of Compensation Terhadap Employee Performance (Studi pada Koperasi Kota Pekalongan). Jurnal Ekonomi \& Ekonomi Syariah Vol 2 No 1, Januari 2019.

Simamora, Henry. (2006). Manajemen Sumber Daya Manusia. Yogyakarta: Sekolah Tinggi IImu Ekonomi YKPN.

Solimun, Adji Achmad Rinaldo Fernandes, dan Nurjannah. (2017). Metode statistika Multivariat Pemodelan Persamaan Struktural SEM, Pendekatan WarpPLS jilid 2. Malang : UB Press.

Spaho, Kenan. (2011). Organizational Communication As An Important Factor of Company Success : Case Study of Bosnia and Herzegovina. Business Intelligence Journal. Center for Technological and Economical Development. Sarajevo.

Steers, Richard M. Gerald R. Ungson and Richard T. Mowday. (1993). Managing Effective Organizations: An Introduction. Boston: Kent Publishing Company.

Sugiyono, (2017). Metode Penelitian Kuantitatif Kualitatif Dan R\&D. Bandung; CV. Alfabeta.

Suranto A.W. (2005). Komunikasi Perkantoran "Prinsip Komunikasi untuk Meningkatkan Kinerja Perkantoran". Yogyakarta: Media Wacana.

Suranto A.W. (2010). Komunikasi Sosial Budaya. Yogyakarta: Grahallmu. Suranto

A.W. (2011). Komunikasi Interpersonal .Yogyakarta: Grahallmu.

Sutrisno, Edy. (2010). Manajemen Sumber Daya Manusia .Jakarta: Kencana Prenada Media Group.

Uno, Hamzah B. (2007). Teori Motivasi \& Pengukurannya Analisis di Bidang Pendidikan. Jakarta: PT Bumi Aksara. 
Pengaruh Keadilan Organisasional Terhadap Perilaku Kerja Kontra Produktif Dan Dampaknya Pada Kepuasan Kerja Pegawai Dinas Sosial Provinsi Kalimantan Barat Iryansah a, b, ... C

Wartulas, Sri. (2003). Pengaruh Motivasi Kerja dan Kepuasan Kerja Guru terhadap Kinerja Guru SMK Negeri Se Kota Semarang. Tesis. Semarang: PPSUniversitas Negeri Semarang.

Widiyanto, M.A. (2013). Statistika Terapan. Jakarta : PT Elex Media

Komputindo.Winardi. (2004). Motivasi Pemotivasian Dalam Manajemen. Jakarta: PT RajaGrafindo Pesada.

Zolin, Roxanne, Renate Frucher \& Pamela Hinds. (2003). Communication, Trust \&Performance: The Influence of Trust on Performance in A/E/C Cross-functional, Geographically Distributed Work. Journal of Productivity and Performance Management, Vol.6 